\title{
Antioxidant Properties of Some Medicinal Plants: Prangos ferulacea (Apiaceae), Sedum sempervivoides (Crassulaceae), Malva neglecta (Malvaceae), Cruciata taurica (Rubiaceae), Rosa pimpinellifolia (Rosaceae), Galium verum subsp. verum (Rubiaceae), Urtica dioica (Urticaceae)
}

\author{
Ahmet Mavi, ${ }^{*, a}$ Zeynep Terzi,${ }^{b}$ Ufuk ÖZgen, ${ }^{b}$ Ali YILdirim, ${ }^{a}$ and Maksut CoşKun ${ }^{c}$ \\ ${ }^{a}$ Kazim Karabekir Education Faculty, Department of Chemistry, Ataturk University; 25240, Erzurum, Turkey: \\ ${ }^{b}$ Department of Pharmacognosy, Faculty of Pharmacy, Ataturk University; 25240, Erzurum, Turkey: and ${ }^{c}$ Department of \\ Pharmaceutical Botany, Faculty of Pharmacy, Ankara University; 06100, Tandodan-Ankara, Turkey. \\ Received October 14, 2003; accepted January 25, 2004
}

\begin{abstract}
Antioxidant and 2,2-diphenyl-1-picrylhydrazyl (DPPH) radical scavenging activities, reducing powers and the amount of total phenolic compounds of aqueous and/or methanolic extracts of some medicinal plants used in Eastern Turkey were studied. These plants are Prangos ferulacea (ÇAşIR), Sedum sempervivoides (Horoz LELESI), Malva neglecta (Eвemgümeci), Cruciata taurica (SARILIK OTU), Rosa pimpinellifolia (Koyun Gózü), Galium verum subsp. verum (MAdAVur OTU), Urtica dioica (IsIRGAN). The highest peroxidation inhibitions were shown by aqueous extracts of $C$. taurica and $R$. pimpinellifolia $\left(\mathrm{IC}_{50}: 0.00022 \mathrm{mg} / \mathrm{l}\right.$ and $\mathrm{IC}_{50}: 23 \mathrm{mg} / \mathrm{l}$, respectively). However, the highest DPPH radical scavenging activity, reducing power and the amount of phenolic compounds were shown by $R$. pimpinellifolia. The lowest antioxidant properties were shown by aqueous extract of $M$. neglecta.
\end{abstract}

Key words antioxidant; radical scavenging; reducing power; phenolic compound; thiobarbituric acid (TBA) test

Reactive oxygen species (ROS) and reactive nitrogen species (RNS) are various forms of activated oxygen and nitrogen, which include free radicals such as superoxide ions $\left(\mathrm{O}_{2}^{-}\right)$, hydroxyl $\left(\mathrm{OH}^{*}\right)$ and nitric oxide radicals $\left.(\mathrm{NO})^{\circ}\right)$, as well as non-free-radical species such as hydrogen peroxide $\left(\mathrm{H}_{2} \mathrm{O}_{2}\right)$ and nitrous acid $\left(\mathrm{HNO}_{2}\right) .{ }^{1-3)}$ In living organisms ROS and RNS can form in different ways. Normal aerobic respiration, stimulated polymorphonuclear leukocytes and macrophages, and peroxisomes appear to be the main endogenous sources of most of the oxidants produced by cells. ${ }^{4-6)}$ Exogenous sources of free radicals include tobacco smoke, ionising radiation, organic solvents and pesticides. $^{7-10)}$ Free radicals can cause lipid peroxidation in foods that leads to their deterioration. ${ }^{11)}$

Oxidation does affect not only lipids. ROS and RNS may cause DNA damage that could lead to mutation. ${ }^{12,13)}$ In addition, ROS and RNS have been implicated in more than 100 diseases, including malaria, acquired immunodeficiency syndrome, heart disease, stroke, arteriosclerosis, diabetes and cancer. ${ }^{6,14-16)}$ When produced in excess, ROS can cause tissue injury, whilst, tissue injury can itself cause ROS generation. ${ }^{12)}$ Nevertheless, all aerobic organisms, including human beings, have antioxidant defenses that protect against oxidative damage and numerous damage removal and repair enzymes to remove or repair damaged molecules. ${ }^{8,17-19)}$ However, the natural antioxidant mechanisms can be inefficient, hence dietary intake of antioxidant compounds becomes important. ${ }^{5,16,20,21)}$ Although there are some synthetic antioxidant compounds, such as butylated hydroxytoluene (BHT) and butylated hydroxyanisole (BHA), which are commonly used in processed foods, it has been reported that these compounds may have side effects. ${ }^{22-28)}$ In addition, it has been suggested that there is an inverse relationship between dietary intake of antioxidant-rich foods and the incidence of a number of human diseases. ${ }^{29,30)}$ Therefore, research into the determination of natural antioxidant sources is important.
In this study, it is aimed to determine the antioxidant activity (AA) and 2,2-diphenyl-1-picrylhydrazyl (DPPH) radical scavenging activity (DPPH-RSA), reducing powers (RP) and amount of total phenolic compounds (APC) of the some medicinal plants which have been used especially in Eastern Turkey.

\section{MATERIALS AND METHODS}

Collection of Plants, Identification and Extraction Seven species which have been used as medicinal plants were collected from villages of Ilica District in Erzurum Province (Turkey). They were authenticated by Dr. Ufuk Özgen and Prof. Dr. Maksut Coşkun. Voucher specimens were deposited Ankara Üniversitesi Eczacılık Fakültesi Herbaryumu (AEF): Prangos ferulacea (L.) LindLey (AEF 21165), Sedum sempervivoides BIEB. (AEF 21141), Malva neglecta WALLR. (AEF 21173), Rosa pimpinellifolia L. (AEF 21147), Cruciata taurica (PAllas ex WiLld.) Ehrend. (AEF 21176), Galium verum $\mathrm{L}$. subsp. verum (AEF 21175), Urtica dioica $\mathrm{L}$. (AEF 21172). Activity studies were performed on decoctions $(5 \%)$ and/or methanolic extracts $(5 \%)$ of used parts of plants in the treatment. Extraction solvents and parts of plants were chosen by taking consideration the usage form of plants by public. Methanol extract was evaporated and then lyophilized, water extract was directly lyophilized. In the AA and DPPH-RSA studies, different concentration ranges were studied and data of 50,100, 250 and $500 \mathrm{mg} / 1$ concentrations were given in all figures.

Determination of Antioxidant Properties The in vitro antioxidant activity tests (Thiobarbituric acid test_-TBA test) were carried out using the lipid peroxidation of liposomes assay where the TBA test has been applied to assess the efficacy of the compounds to protect liposomes from lipid peroxidation. ${ }^{31)}$ Propyl gallate was used as a positive control. Data are given as \% peroxidation inhibition-concentration 


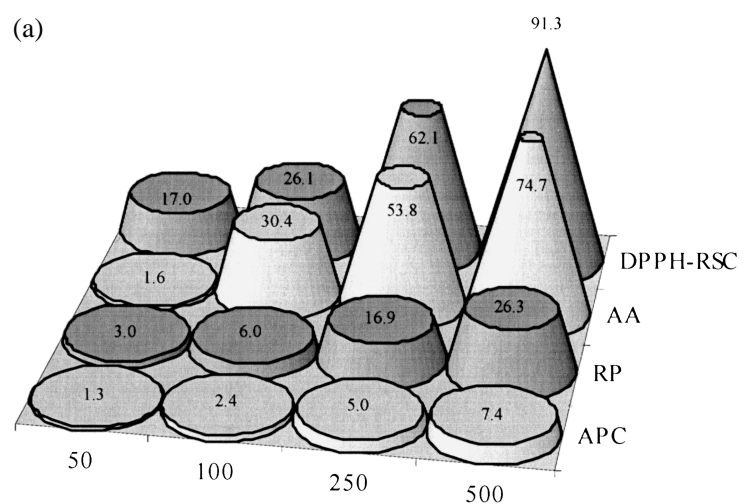

Extract Concentration ( $\mathrm{mg} / \mathrm{l})$

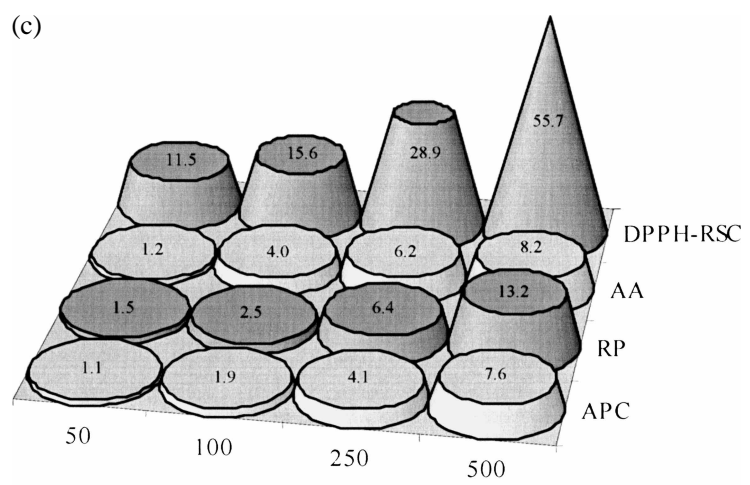

Extract Concentration ( $\mathrm{mg} / \mathrm{l})$

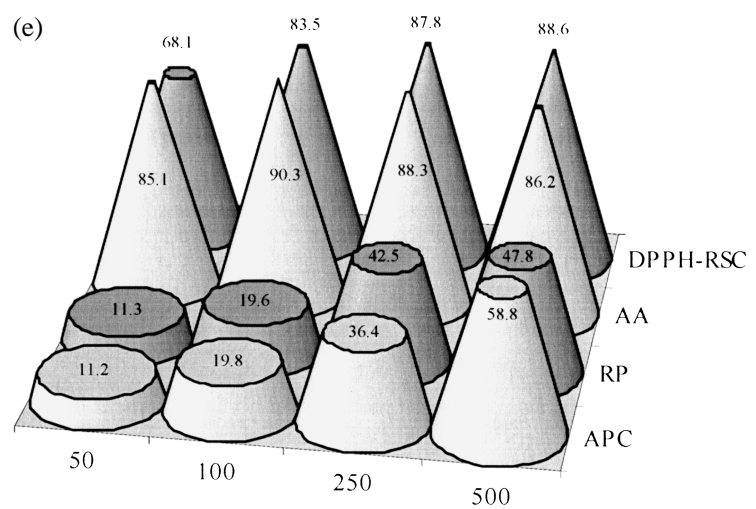

Extract Concentration $(\mathrm{mg} / \mathrm{l})$

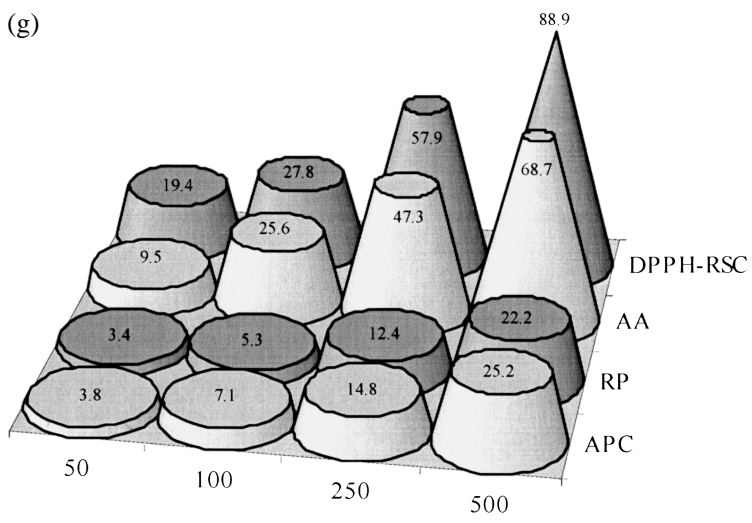

Extract Concentration ( $\mathrm{mg} / \mathrm{l}$ )

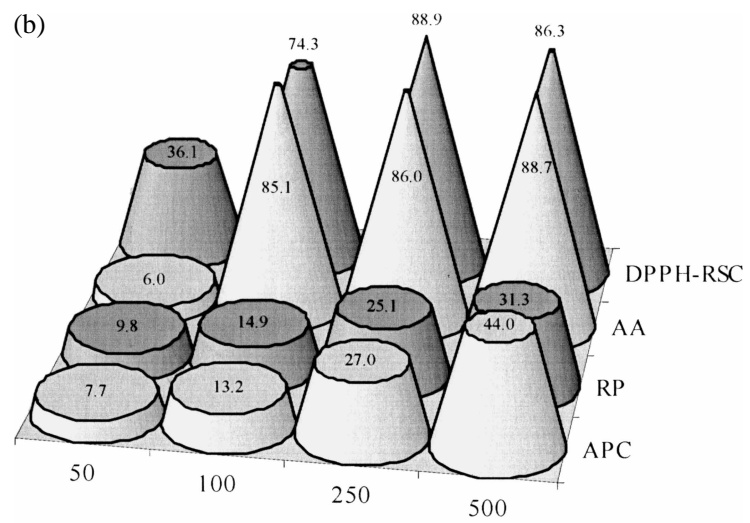

Extract Concentration $(\mathrm{mg} / \mathrm{l})$

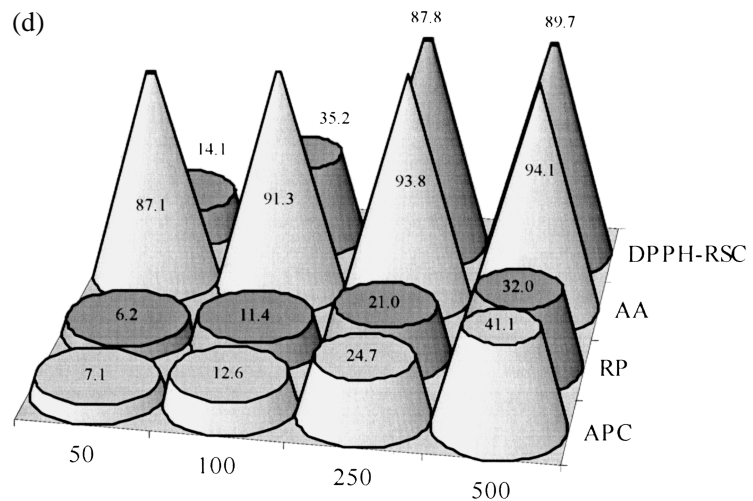

Extract Concentration ( $\mathrm{mg} / \mathrm{l})$

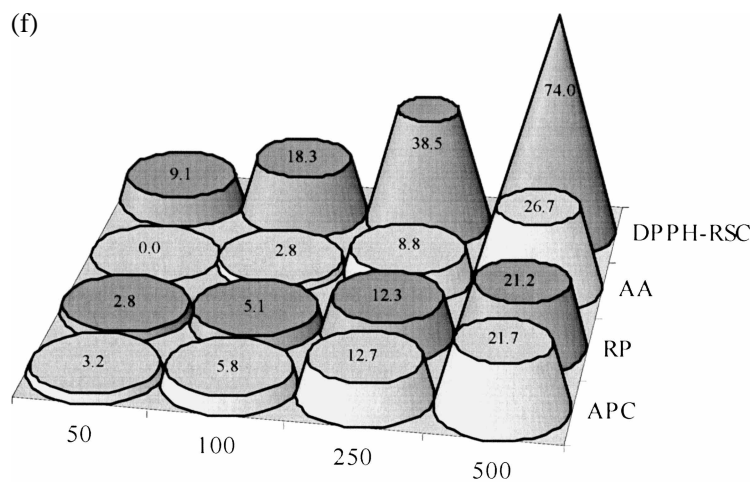

Extract Concentration (mg/l)

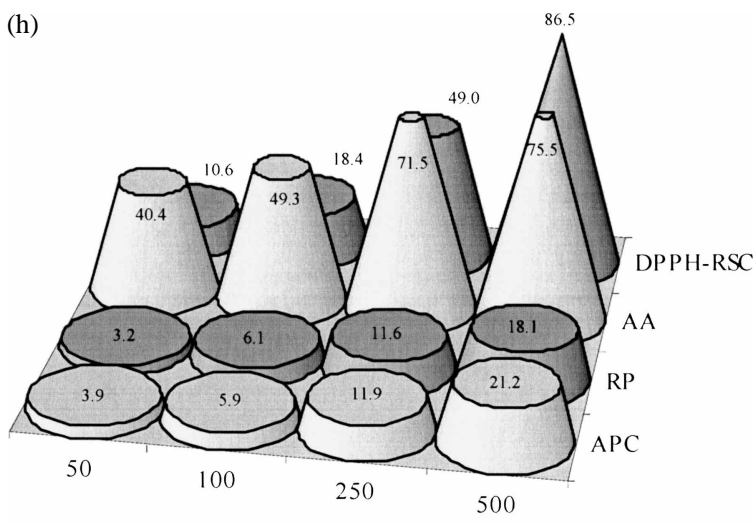

Extract Concentration ( $\mathrm{mg} / \mathrm{l})$

Fig. 1. Antioxidant Properties of (a) Methanolic Extract of P. ferulaceae Stems, (b) Aqueous Extract of S. sempervivoides, (c) Aqueous Extracts of M. neglecta, (d) Aqueous Extracts of C. taurica, (e) Aqueous Extracts of R. pimpinellifolia Fruits, (f) Aqueous Extracts of $U$. dioica, (g) Aqueous Extracts of $G$. verum, and (h) Methanolic Extracts of G. verum

APC: amount of phenolic compound, RP: reducing power, AA: antioxidant activity, DPPH-RSC: DPPH radical scavenging activity. 


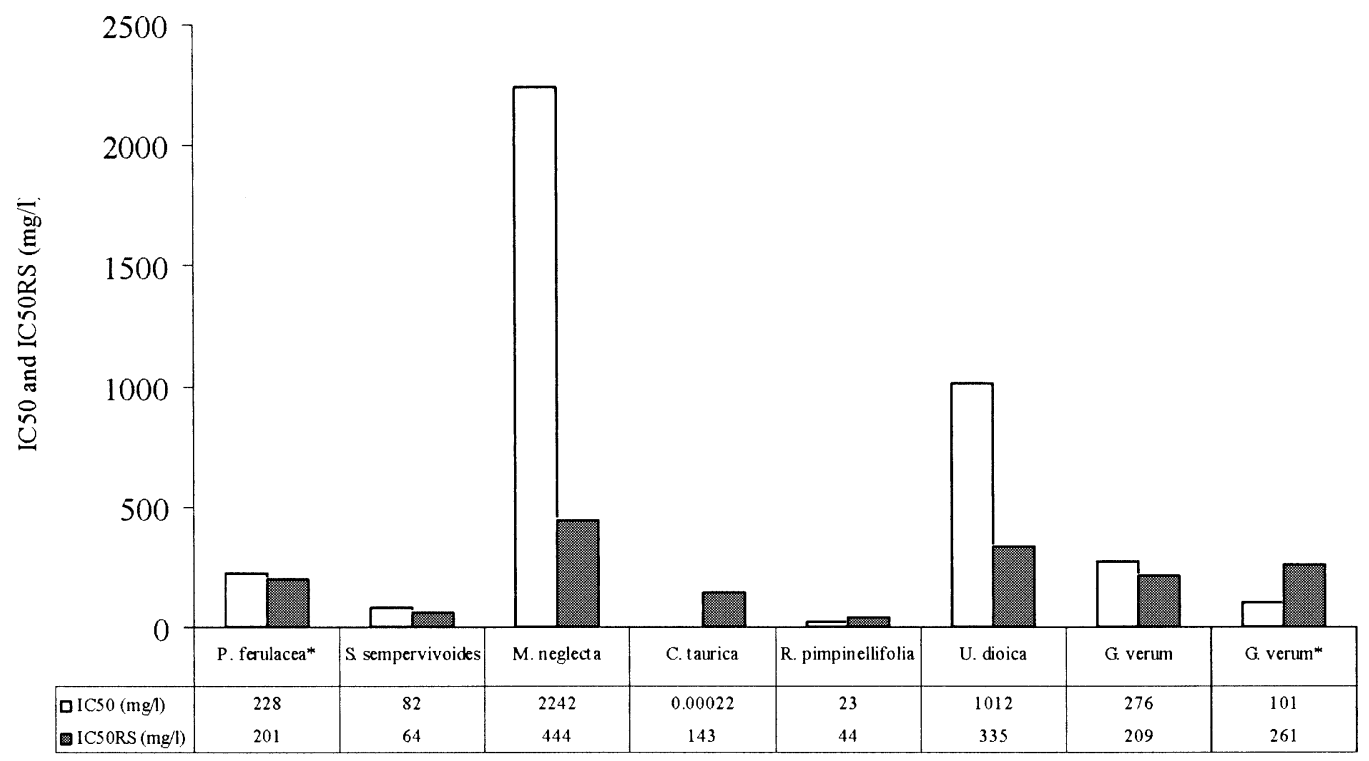

Fig. 2. $\mathrm{IC}_{50}$ and $\mathrm{IC}_{50} \mathrm{RS}$ Values of Extracts

* Methanolic extract $\left(\mathrm{IC}_{50}: \mathrm{mg} / 1\right.$ extract concentration required for $50 \%$ peroxidation inhibition, $\mathrm{IC}_{50} \mathrm{RS}: \mathrm{mg} / 1$ extract concentration required for $50 \%$ inhibition of the DPPH radical absorbance at $517 \mathrm{~nm}$ ).

graphic and $\mathrm{IC}_{50}(\mathrm{mg} / \mathrm{l}$ extract concentration required for $50 \%$ peroxidation inhibition).

DPPH radical-scavenging activities were determined according to Cakir et al. ${ }^{32)}$ This activity is given as $\mathrm{IC}_{50} \mathrm{RS}$ (mg/l extract concentration required for 50\% inhibition of the DPPH radical absorbance at $517 \mathrm{~nm}$ ) and \% DPPH radical scavenging that is calculated in equation;

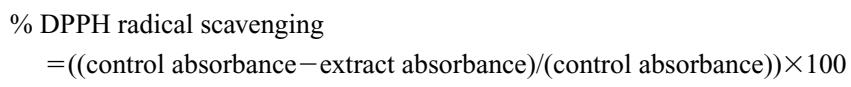

Control was the test solution without extract.

Reducing power assays were carried out as described previously. ${ }^{33)}$ Reducing powers of the extracts were expressed as ascorbic acid equivalent (Asc. Acid Eq.) using calibration curve.

Determination of amount of total phenolic compounds was carried out as described previously. ${ }^{34)}$ Gallic acid was used as a standard phenolic compound. The phenolic compound content was determined as gallic acid equivalent using calibration curve.

\section{RESULTS}

All extracts show antioxidant potential (Figs. 1a-h). The highest peroxidation inhibitions are shown by aqueous extracts of $C$. taurica and $R$. pimpinellifolia $\left(\mathrm{IC}_{50}: 0.00022 \mathrm{mg} / \mathrm{l}\right.$ and $\mathrm{IC}_{50}: 23 \mathrm{mg} / 1$, respectively in Fig. 2). Extracts, which have relatively higher APC, have relatively higher peroxidation inhibition ability except methanolic extract of $G$. verum. In all extracts, there is a statistically significant correlation between RP and APC. However, there is no correlation between DPPH-RSA and APC in S. sempervivoides, C. taurica, $R$. pimpinellifolia, and between AA and APC in S. sempervivoides, $C$. taurica, $R$. pimpinellifolia, $M$. neglecta and methanol extract of $G$. verum. Methanolic extracts of $G$. verum has more effective peroxidation inhibition ability although relatively lower APC than its water extract. In addition, although it has about the same APC with $U$. dioica, it is more effective antioxidant.

\section{DISCUSSION}

These plants have various compounds ${ }^{35-54)}$ and also the most of them contain phenolic compounds, especially flavonoids. Flavonoids generally have antioxidant potential. ${ }^{55)}$ Therefore, their AA, DPPH-RSA, RP could be caused by these phenolic compounds. As can be seen form the Figs. 1a-h, extracts which have high APC also have high AA.

Peroxidation is a chain reaction which can be initiated by a reactive radical abstracting an electron from a nonradical. Thus, a radical is transformed to a nonradical. However, simultaneously a new radical can be formed and so reaction can continue. In the presence of phenolic compounds, hydrogen with an electron can be donated from phenolics, thus radical can be scavenged. Because of the resonance stability, newly formed phenoxy radical is more stable than former radical. Thus, chain reactions can be retarded. ${ }^{7)}$ In addition, easily donating an electron is an indicator of RP of an extract. A statistically significant correlation between RP and APC in all extracts supports this $(p<0.05)$.

In contrast to RP and APC, there is no correlation between DPPH-RSA and APC, between AA and APC in the some extracts. AA and DPPH-RSA values of extracts which have relatively higher APC reached the maximum level at lower concentrations than $500 \mathrm{mg} / \mathrm{l}$ (Figs. 1b, d, e). Therefore, concentration dependent increasing of activities is not like that of APC assay. Therefore, we could not find a correlation between these.

Methanol extract of $G$. verum has higher AA than its water extract. In contrast, DPPH-RSA, RP and APC of methanolic extract are lower than water extract. At first glance, it can be thought as a contradiction. Nevertheless, it should be kept in mind that $\mathrm{AA}$ is the consequence of cooperative behaviors of all antioxidant properties (e.g. radical scavenging, reducing power, decomposition of peroxides). ${ }^{32)}$ In addition, solubility of a phenolic compound in the peroxidation environment can 
affect its activity. In the AA assay, we used bovine brain homogenate which consist of a polar tampon phase and an apolar biological mater phase. Methanolic extract contains more apolar compounds than water extract. Decrease in the polarity of a compound causes an increase of solubility of the compound in the apolar phase in which peroxidation occur. Therefore, methanolic extract of $G$. verum can be more effective antioxidant than its water extract.

\section{REFERENCES}

1) Halliwell B., Biochem. Soc. Symp., 61, 73-101 (1995).

2) Halliwell B., Aruoma O. I., "Antioxidant Methodology in Vivo and in Vitro Concepts," ed. by Aruoma O. I., Cuppett S. L., AOCS Press, Illionis, 1997, pp. 1-22.

3) Squadrito G. L., Pryor W. A., Free Radic. Biol. Med., 25, 392-403 (1998).

4) Fridovich I., Adv. Enzymol. Ramb., 58, 61—97 (1986).

5) Halliwell B., Lancet, 344, 721-724 (1994).

6) Alho H., Leinonen J., Method. Enzymol., 299, 3-15 (1999).

7) Halliwell B., Gutteridge J. M., "Free Radicals in Biology and Medicine," Clarendon Press, Oxford, 1989, pp. 23-30.

8) Davies K. J. A., Biochem. Soc. Symp., 61, 1-31 (1995).

9) Papas A. M., Lipids, 31, 77-82 (1996).

10) Robinson E. E., Maxwell S. R. J., Thorpe G. H. G., Free Radical Res., 26, 291-302 (1997).

11) Sasaki S., Ohta T., Decker E. A., J. Agr. Food Chem., 44, 1682-1686 (1996).

12) Aruoma O. I., J. Am. Oil Chem. Soc., 75, 199-212 (1998).

13) Sawa T., Nakao M., Akaike T., Ono K., Maeda H., J. Agr. Food Chem., 47, 397-402 (1999).

14) Tanizawa H., Ohkawa Y., Takino Y., Miyase T., Ueno A., Kageyama T., Hara S., Chem. Pharm. Bull., 40, 1940-1942 (1992).

15) Hertog M. G. L., Feskens E. J. M., Hollman P. C. H., Katan M. B., Kromhout D., Lancet, 342, 1007-1011 (1993).

16) Duh P. D., J. Am. Oil Chem. Soc., 75, 455-461 (1998).

17) Granelli K., Björck L., Appelqvist L. A., J. Sci. Food Agr., 67, 85-91 (1995).

18) Fridovich I., Annu. Rev. Biochem., 64, 97-112 (1995)

19) Sun J., Chen Y., Li M. T., Ge Z. L., Free Radic. Biol. Med., 24, 586593 (1998)

20) Terao J., Piskula M., Yao Q., Arch. Biochem. Biophys., 308, 278-284 (1994).

21) Espin J. C., Soler-Rivas C., Wichers H. J., J. Agr. Food Chem., 48, 648-656 (2000)

22) Branen A. L., J. Am. Oil Chem. Soc., 52, 59-63 (1975).

23) Lindenschmidt R. C., Tryka A. F., Goad M. E., Witschi H. P., Toxicology, 38, 151-160 (1986).

24) Witschi H. P., Toxicology, 21, 95-104 (1981).

25) Patterson R. M., Keith L. A., Stewart J., Toxicol. In Vitro, 1, 55-57 (1987).

26) Kehrer J. P., DiGiovanni J., Toxicol. Lett., 52, 55-61 (1990).
27) Takahashi O., Sakamoto Y., Hiraga K., Toxicol. Lett., 27, 15-25 (1985).

28) Yamamoto K., Tajima K., Mizutani T., Toxicol. Lett., 6, 173-175 (1980).

29) Rice-Evans C. A., Sampson J., Bramley P. M., Holloway D. E., Free Radical Res., 26, 381-398 (1997).

30) Lu Y. R., Foo L. Y., Food Chem., 68, 81-85 (2000).

31) Fernàndez J., Pèrez-Alvarez J., Fernàndez-Lopez J., Food Chem., 59, 345-353 (1997).

32) Cakir A., Mavi A., Yıldırım A., Duru M. E., Harmandar M., Kazaz C., J. Ethnopharmacol., 87, 73-83 (2003).

33) Yıldırım A., Oktay M., Bilaloğlu V., Turkish J. Med. Sci., 31, 23-27 (2001).

34) Singleton V. L., Orthofer R., Lamuela-Raventos R. M., Method. Enzymol., 299, 152-178 (1999).

35) Stevens J. F., Hart H., Hendriks H., Malingre T. M., Phytochemistry, 31, 3917-3924 (1992).

36) Stevens J. F., Hart H., Elema E. T., Bolck A., Phytochemistry, 41 , 503-512 (1996).

37) Tanker M., Ergun F., J. Fac. Pharm. Ankara, 13, 89-100 (1983).

38) Ergun F., Küsmenoğlu S., Sener B., J. Liq. Chromatogr., 7, 16851689 (1984).

39) De Rosa S., Mitova M., Handjieva N., Çalıs İ., Phytochemistry, 59, $447-450$ (2002)

40) Temizer A., Kir S., Ergun F., Sener B., J. Chem. Soc. Pakistan, 17, 180-182 (1995).

41) Ergun F., Sener B., J. Fac. Pharm. Gazi, 3, 59-63 (1986).

42) Mitova M. I., Anchev M. E., Handjieva N. V., Popova S. S., Zeitschrift fur Naturforschung C-A Journal of Biosciences, 57, 226-234 (2002).

43) Bojthe Horvath K., Hetenyi F., Kocsis A., Szabo L., Varga Balazs M., Mathe I., Tetenyi P., Phytochemistry, 21, 2917-2919 (1982).

44) Borisov M. I., Kovalev V. N., Zaitsev V. G., Khim. Prir. Soedin., 7, 529-530 (1971).

45) Pijewska L., Pol. J. Pharmacol. Pharm., 25, 465-467 (1973).

46) Raynaud J., Mnajed H., C. R. Acad. Sci. D, 274, 1746-1748 (1972).

47) Basaran A. A., Akbay P., Ündeger Ü., Basaran N., Toxicology, 164, $171-172(2001)$.

48) Guil-Guerrero J. L., Rebolloso-Fuentes M. M., Isasa M. E. T., J. Food Compos. Anal., 16, 111-119 (2003).

49) Ligai L. V., Rakhimov D. A., Bandyukova V. A., Khim. Prir. Soedin., 2, 280-281 (1989)

50) Abyshev A. Z., Khim. Prir. Soedin., 4, 130-131 (1968).

51) Abyshev A. Z., Denisenko P. P., Kostyuchenko N. P., Anisimova O. S., Ermakov A. I., Sheinker Y. N., Khim. Prir. Soedin., 6, 675-680 (1970).

52) Nikonov G. K., Saidkhodzhaev A. I., Khim. Prir. Soedin., 7, 255-257 (1971).

53) Abyshev A. Z., Khim. Prir. Soedin., 5, 568-574 (1974).

54) Plekhanova T. I., Bandyukova V. A., Bairamkulova F. K., Khim. Prir. Soedin., 3, 398 (1978).

55) Hall C. A., Cuppett S. L., "Structure-Activities of Natural Antioxidants," ed. by Aruoma O. I., Cuppett S. L., AOCS Press, Illinois, 1997, pp. $141-172$. 